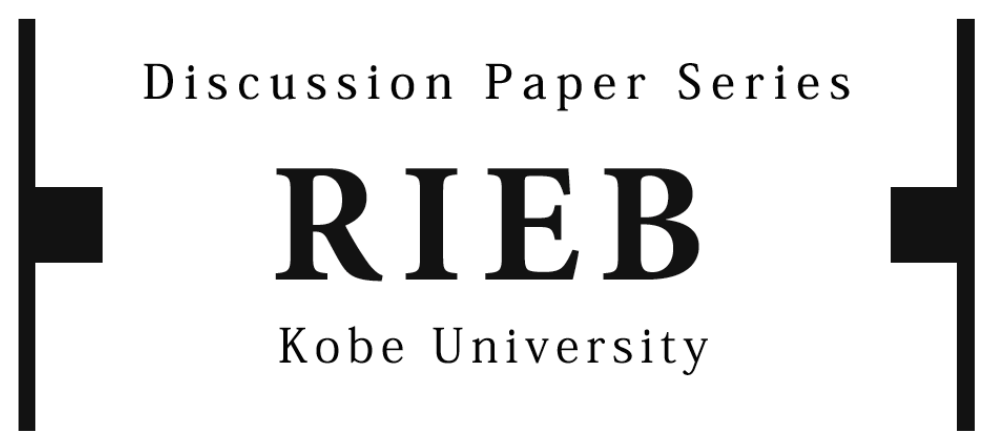

DP2016-27

\title{
Dynamic and Long-term Linkages among Agricultural and Non-Agricultural Growth, Inequality and Poverty in Developing Countries*
}

\author{
Katsushi S. IMAI \\ Wenya CHENG \\ Raghav GAIHA
}

\section{August 18, 2016}

* The Discussion Papers are a series of research papers in their draft form, circulated to encourage discussion and comment. Citation and use of such a paper should take account of its provisional character. In some cases, a written consent of the author may be required.

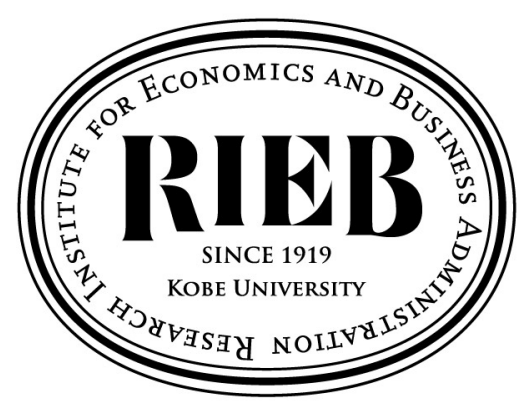

Research Institute for Economics and Business Administration

Kobe University

2-1 Rokkodai, Nada, Kobe 657-8501 JAPAN 


\title{
Dynamic and Long-term Linkages among Agricultural and Non-Agricultural Growth, Inequality and Poverty in Developing Countries
}

\author{
Katsushi S. Imai * \\ Economics, School of Social Sciences, University of Manchester, Arthur Lewis Building, Oxford Road, \\ Manchester M13 9PL, UK \& RIEB, Kobe University Japan; Email: Katsushi.Imai@ manchester.ac.uk \\ Wenya Cheng \\ Economics, School of Social Sciences, University of Manchester, Arthur Lewis Building, Oxford Road, \\ Manchester M13 9PL, UK; Email: Wenya.Cheng@manchester.ac.uk \\ Raghav Gaiha \\ Faculty of Management Studies, University of Delhi, Delhi, India, \& Department of Global Health and \\ Population,, Harvard School of Public Health, Harvard University Boston, USA; Email: \\ raghavdasgaiha@gmail.com
}

\begin{abstract}
Drawing upon cross-country panel data for developing countries, the present study examines the role of agricultural growth in reducing inequality and poverty by modelling the dynamic linkage between agricultural and non-agricultural sectors. For this purpose, we have compared the role of agricultural growth and that of non-agricultural growth and have found that agricultural growth is more important in reducing poverty, while the negative effect of agricultural growth on inequality is found in a few models where specific definitions of inequality are adopted. Our analysis generally reinforces the case for revival of agriculture in the post-2015 discourse, contrary to the much emphasised roles of rural-urban migration and urbanisation as main drivers of growth and elimination of extreme poverty.
\end{abstract}

Keywords: Inequality, Poverty, Growth, Agriculture, Non-agriculture, MDG, SDG

JEL Codes: C20, I15, I39, O13

\section{*Corresponding Author:}

Katsushi S. Imai (Dr)

Economics, School of Social Sciences,

University of Manchester, Arthur Lewis Building,

Oxford Road, Manchester M13 9PL, UK

Phone: +44-(0)161-275-4827; Fax: +44-(0)161-275-4928; E-mail:

Katsushi.Imai@manchester.ac.uk

\section{Acknowledgements}

This study is funded by IFAD (International Fund for Agricultural Development). We are grateful to Thomas Elhaut, Director for his enthusiastic support and guidance throughout this study and for his insistence on highest standards of analytical rigour. The third author thanks David Bloom for his advice and support. We also thank Adams Sorekuong Adama and Abdi Ali for providing the price uncertainty data of export prices. The views expressed are personal and not necessarily of the organisations to which we are affiliated or of IFAD. 


\section{Dynamic and Long-term Linkages among Agricultural and Non-Agricultural Growth, Inequality and Poverty in Developing Countries}

\section{Introduction}

The main objective of this study is to examine the role of agricultural growth in reducing inequality and poverty using cross-country panel data for developing countries. To achieve this objective, we compare the roles of agricultural growth and non-agricultural growth in poverty and inequality reduction by modelling the linkage between agricultural and non-agricultural sectors. Both poverty headcount ratios and poverty gaps are used as measures of poverty. More broadly, we aim to re-establish the role of agricultural growth - mainly because recent studies by the World Bank (e.g. The Global Monitoring Report 2013 (World Bank, 2013)) and others have questioned the primacy of agricultural growth in stimulating overall growth and reduction of poverty. As a persuasive case for stimulating agricultural growth and poverty reduction was made by World Development Report 2008 (World Bank, 2007), it is necessary to examine it in light of more recent evidence. Given the goal of elimination of extreme poverty by 2030, and the lively discourse on the post-2015 development agenda, a careful determination of sectoral growth priorities is imperative.

It is claimed by the World Bank (2013) and Chandy et al. (2011), among others, that the Millennium Development Goal (MDG) $1 \mathrm{~A}^{1}$ of halving extreme poverty by 2015 was achieved in 2010 - five years ahead of the deadline. Yet 970 million will remain poor in 2015, with 84 per cent concentrated in South Asia and Sub-Saharan Africa. The latter is also the only region that

\footnotetext{
${ }^{1}$ MDG1A aimed to "Halve, between 1990 and 2015, the proportion of people whose income is less than $\$ 1.25$ a day". This has led to Sustainable Development Goal (SDG): "By 2030, eradicate extreme poverty for all people everywhere, currently measured as people living on less than $\$ 1.25$ a day" (https://sustainabledevelopment.un.org/sdg1).
} 
was expected not to achieve MDG $1 \mathrm{~A}$ by 2015 . It should also be noted that global poverty remains a rural problem with more than three-fourths of the extremely poor located in rural areas. However, as global poverty fell, so did the gap between rural-urban poverty. It reduced by half in East Asia and the Pacific by 2008, while in Sub-Saharan Africa, Latin America and the Caribbean, and South Asia, there was less progress. World Bank (2013) also makes an important contribution to the discourse on MDGs by disaggregating progress into rural and urban components. In doing so, it offers striking examples of the continuing rural-urban disparities in several MDGs. It does not, however, disaggregate the 970 million that remained in extreme poverty in 2015 into those who were in rural and urban areas, respectively. This is crucial for designing appropriate policy interventions for rural and urban areas.

Much of sustained reduction in poverty hinges on how growth and inequality interact - a subject that has gained prominence in a context of rising inequality in a large part of the developing world in the last two decades. As argued in a recent UN report (United Nations, 2013), addressing inequality is not just a moral imperative but a necessity for sustainable development. Evidence points to the powerful and corrosive effects of inequality on poverty reduction, social cohesion and stability. A major part of the solution lies in fostering inclusive and sustainable rural transformation through a comprehensive approach to food security and nutrition, addressing the linkages between agriculture, health, education, water, energy, gender equity and poverty. Both poverty and inequality reduction are clearly featured in the Sustainable Development Goals (SDGs), or the 2030 Agenda for Sustainable Development, which were agreed at United Nations Sustainable Development Summit 2015 in September 2015.

The present study departs from the extant literature in the following ways. First, as an extension of Christiaensen et al. (2011), we will estimate the dynamic linkages between 
agricultural growth and non-agricultural growth using a dynamic panel model applied to crosscounty panel data (Blundell and Bond, 1998). We will apply this model separately for nonagricultural sector growth and agricultural sector growth in which both lagged agricultural growth and lagged non-agricultural growth are used as explanatory variables in each model after taking account of the endogeneity of the past growth of both sectors. This will enable us to estimate effects from the non-agricultural sector to the agricultural sector, and vice versa. For instance, the improvement in productivity in the agricultural sector (e.g. through the shift from basic staple food production to high yield varieties or non-staple food production) is likely to have positive effects on non-agricultural growth, while the non-agricultural sector growth may impact the agricultural sector through the change in demand patterns for primary goods. Second, we will estimate the effects of agricultural and non-agricultural growth terms as predictions of the dynamic panel model on inequality and poverty. This focuses on the dynamic role of agricultural growth - in comparison with that of non-agricultural growth - in reducing not only poverty, but also inequality. We have thus extended Christiaensen et al. (2011) by using different models and more recent data, including the comprehensive data on inequality.

The rest of the paper is structured as follows. Section 2 offers a brief explanation of the relationship between the agricultural sector and the non-agricultural sector. Section 3 reviews the empirical literature. We will then summarise the data sources in Section 4. Section 5 elaborates the econometric models we will employ. Regression results are discussed in Section 6. Section 7 offers concluding remarks with policy implications.

\section{The relationship between the agricultural sector and the non-agricultural sector}


To motivate our empirical analysis, we will first provide a brief theoretical explanation of the relationship between the agricultural sector and the non-agricultural sector. Emphasising the role of agricultural sector in overall development, earlier seminal works by Johnston and Mellor (1961) and Mellor (1966) argued that agriculture will make a net contribution to the capital required for overhead investment and expansion of secondary industry and that rising net cash income of the farm population will be important as a stimulus to expansion of the non-farm sector. Later, Christiaensen et al. (2011) focused more on dynamic interactions between the agricultural and non-agricultural sectors. First, agricultural production can be interlinked with non-agricultural production, for instance, modernization of agriculture would require the use of chemical fertilizers, pesticides, machine services, processed seeds, or fuels, which would promote non-agricultural production (e.g. Restuccia et al., 2008). Second, increase in agricultural income (or non-agricultural income) will lead to increased demand for non-agricultural products (or raw or processed agricultural products). Third, decrease in food prices as a result of agricultural growth will result in better food security and overall poverty reduction in both rural and urban areas, while the reduction of food price would lower the real product wage in nonagriculture, thereby raising profitability and investment in that sector (Christiaensen et al., 2011).

Our empirical model can be broadly motivated by the theoretical model of Restuccia et al. (2008) who put forward a two-sector general-equilibrium model with the production and consumption of two final goods: an agricultural good and a non-agricultural good where agricultural production uses an intermediate input, which is supplied by the non-agricultural sector. They showed that barriers to using modern inputs or inability to transform traditional agricultural sectors explain stagnation of the agricultural sector, while interactions between agricultural and non-agricultural sectors will promote agricultural growth. 


\section{The Literature Review}

Despite the large body of literature demonstrating the role of agricultural growth in overall economic growth and poverty, rigorous empirical analyses of the role of growth in both agricultural and non-agricultural sectors and their interactions are still few and far between, with a few exceptions such as Haggblade and Hazell (1989), Haggblade et al. (2007), de Janvry and Sadoulet (2010) and Christiaensen et al. (2011). Haggblade and Hazell (1989) used cross-country data (43 countries) and illustrated the close interaction between these sectors, based on statistical comparisons of agricultural income and non-farm sector employment share. Haggblade et al. (2007) reported large multiplier or indirect effect from agricultural sector to non-agricultural sector. $^{2}$ de Janvry and Sadoulet (2010) reviewed several empirical studies, including their own on China and Vietnam, that confirm substantial sectoral linkages and their poverty reduction potential. More recently, Timmer (2015) focused on the structural transformation and the longrun dynamic evolution of the rice-based systems in Southeast Asia and he argued that agricultural growth gives most households access to the food in their fields and markets, resulting in their improved food security and poverty. Imai et al. (2016) have found that an increase in population share in agriculture is associated with poverty reduction once the longerterm poverty change or the dynamic is taken into account. Rehman et al. (2016) also emphasised the importance of agriculture for the reduction of poverty because in developing countries the poor rely on agriculture for employment and have limited skills to enter into the non-agricultural sector.

\footnotetext{
${ }^{2}$ Haggblade et al. (2007) give evidence on multiplier effects of agricultural sector using an input-output model for developing countries.
} 
Chistiaensen et al. (2011) is the first rigorous work in the empirical literature to estimate the dynamic linkages between agricultural growth and non-agricultural growth as well as those between these sectoral growth components and poverty, drawing upon a cross-country panel dataset. They applied a dynamic panel model to take into account the dynamic realisation of agricultural growth (or non-agricultural growth) by having lagged dependent variables, while considering the dynamic effect of non-agricultural growth (or agricultural growth) on agricultural growth (or non-agricultural growth) over time. Their estimation strategy (System GMM) is based on Arellano and Bover (1995) and Blundell and Bond (1998) with the finite sample correction of the two-step standard errors proposed by Windmeijer (2005). The present analysis also uses the Blundell and Bond estimator with the Windmeijer correction. More specifically, our model consists of two stages where in the first stage agricultural (or nonagricultural) growth is estimated by non-agricultural (or agricultural) growth and, in the second, inequality (or poverty) is estimated by (predicted) values of agricultural and non-agricultural growth. The empirical strategy will be discussed in detail in Section 5.

\section{Data}

The data for the first set of analyses of the effects of agricultural and non-agricultural growth on inequality or poverty are mainly based on World Development Indicators (WDI) 2011, 2012, 2013 and 2014 (e.g. World Bank, 2014). The data on education and a few other variables are based on Barro and Lee (2010). To construct the proxy for institutional qualities, we have used the World Bank's World Governance Indicators (http://info.worldbank.org/governance/wgi/index.asp). We have derived the simple average of four indicators, voice and accountability, political stability and absence of violence, rule of law 
and control of corruption to capture the overall quality of institutions. While Christiaensen et al. (2011) uses the three-year averaged data over the period 1960-2005 for a sample of 85 countries and 588 observations in their main specification (the columns (1) of Table 3 in Christiaensen et al.), the present study covers the period 1969-2010 for 59 countries and 532 observations (Case 1, Table 1). The list of countries is given in Appendix 1. The difference is due to the fact that we have updated the data and have used a different set of explanatory variables. Following Christiaensen et al. (2011), our analysis is mainly based on the three-year averaged data, but we have also used annual panel as well as the five-year average panel as robustness checks.

We will adopt three kinds of inequality measures. First, following Herzer and Vollmer's (2012) work which estimated the relationship between economic growth and inequality, we have used the inequality data based on the EHII data - derived from the relationship between UTIPUNIDO, other conditioning variables, and the World Bank's Deininger and Squire data set. This is taken from the University of Texas Inequality Project (http://utip.gov.utexas.edu/data.html). Herzer and Vollmer (2012) selected 46 countries for the period 1970-2008 to minimise the problem of missing observations given that they apply the panel co-integration method. The EHII dataset is based on Theil's T statistic measured across sectors within each country where the classifications of sectors are standardized, based on UNIDO's Industrial Statistics and Eurostat to facilitate international comparisons. While we use the EHII data on inequality, it will not be sufficient to use the data for only 18 developing countries, as in Herzer and Vollmer (2012), for the purpose of deriving any useful policy implications for developing countries. Apart from policy considerations, it may not be appropriate either - as a serious empirical work to test economic theories - to pool both developed and developing countries overlooking the structural difference between developed and developing economies (e.g. incomplete credit and 
insurance markets in the latter). We have thus constructed an unbalanced panel data for inequality based on the EHII data covering a larger number of countries (86 countries) for a longer period (1970-2008). Besides, we have further expanded the EHII data on inequality by supplementing them with the World Bank data (World Bank, 2014) on inequality (the Gini Index) on the PovcalNet, by estimating the EHII data on inequality by the World Bank data (World Bank 2014) using Ordinary Least Squares and replacing the missing observations by the 'out-of-sample' predictions. With this method, we have managed to cover 119 countries, including 49 countries $^{3}$ in the first set of analyses. ${ }^{4}$ Although the data quality and comparability are not ideal, this method has the advantage of covering more countries (about six times more developing countries than in Herzer and Vollmer (2012)). While the UTIP-UNIDO dataset on pay inequality is based on global pay inequality data, Galbraith and Kum (2005) have shown that this is highly correlated with the Deininger and Squire's (1996) Gini measure of inequality and it is thus reasonable to assume that the EHII dataset is one of the best data sources for inequality analyses of developing countries in terms of its coverage of countries. In our case coefficient of correlation between the EHII data on inequality and the Gini coefficient is 0.723 . However, the limitation of the EHII dataset should be noted as it does not cover self-employment data or the agricultural wage data and may be a poor proxy for inequality of low income countries relying on agricultural sectors. Second, given the limitations of the EHII dataset, we will also use the World Bank's Gini index. While this is widely used, a major limitation of the Gini index in our study context is that the coverage of countries/years is highly limited. Third, we will also use the 'raw' EHII data of inequality without aforementioned adjustment. In this case the coverage of years/countries is also limited. Although each indicator has its own limitations, we will apply

\footnotetext{
${ }^{3}$ The number of countries varies from 40 to 49 depending on which specification we use for the inequality estimation.

${ }^{4}$ Descriptive statistics are found in Appendix 2.
} 
these three measures in our empirical analyses. On poverty data we will follow Christiaensen et al. (2011) and use the World Bank's POVCAL data as well as World Development Indicators 2014 to derive the international poverty estimates, that is, poverty headcounts and poverty gaps ${ }^{5}$ based on US\$1.25 and US\$2 (in Purchasing Power Parity in 2005).

\section{Econometric Models}

\section{$1^{\text {st }}$ Stage: estimation of non-agricultural growth and agricultural growth}

Given the persistence of non-agricultural income growth (defined as the first difference in value added in the industrial and service sectors), the dynamic panel data model is specified as follows.

$\Delta Y^{N A}{ }_{i t}=\sum_{j=1}^{P} \alpha_{j} \Delta Y^{N A}{ }_{i t-j}+\sum_{j=1}^{Q} \gamma_{j} \Delta Y^{A}{ }_{i t-j}+\boldsymbol{X}_{i t} \cdot \beta_{1}+\boldsymbol{Z}_{i t} \cdot \beta_{2}+\eta_{i}+\varepsilon_{i t}$

where $i$ and $t$ denote country and time (3- year averages, that is, from 1969-72, 73-75,.., 20082010) ${ }^{6}, \Delta Y^{N A}{ }_{i t}$ is the first difference in log of non-agricultural value added per capita, and $\Delta Y^{N A}{ }_{i t-j}$ is its $j^{\text {th }}$ lag. $\Delta Y^{A}{ }_{i t}$ is the first difference in log of agricultural value added per capita, which is modelled as an endogenous variable. $\boldsymbol{X}_{i t}$ is a vector of explanatory variables (exogenous variables, such as precipitation) and $\boldsymbol{Z}_{i t}$ is a vector of endogenous variables. $Z_{i t}$ includes the share of mining sector income in GDP (second lagged), the first difference in log

\footnotetext{
${ }^{5}$ These are the most commonly-used poverty measures based on the Foster, Greer and Thorbecke (FGT, 1984). Poverty headcount (FGT0) is the fraction of the population that lives below the poverty line, while poverty gap (FGT1) considers the depth of poverty. Similar results were obtained if we used the squared poverty gap (FGT2) measure which weighs income inequality among the poor, but we will report only the results based on poverty headcount and poverty gap due to the space limitation.

${ }^{6}$ Our use of 3 years average panel data follows Christiaensen et al. (2011). We have also used annual and 5 years average panel datasets. Our discussions are mainly based on the results of 3 years average panel as the results based on annual panel data tend to be influenced by business cycle and short-term fluctuations or shocks, which may not have an immediate impact on inequality or poverty and the number of the observations will be reduced in case we use 5 years average data.
} 
of investment ${ }^{7}$, and log of schooling years (first lag). While we will examine the effects of predicted agricultural and non-agricultural growth on inequality in the second stage, we will insert the (endogenous) inequality in one of the specifications to see whether inequality has any impact on non-agricultural growth. In one specification, we have interacted $\Delta Y^{A}{ }_{i t}$ with the SubSaharan African dummy (SSA) to see if the effect of agricultural growth on non-agricultural growth is different in SSA and elsewhere, following Christiaensen et al. (2011). $\eta_{i}$ is the country-specific unobservable (e.g. social and cultural factors) and $\varepsilon_{i t}$ is an error term, independent, and identically distributed (or i.i.d.).

As an alternative to the standard first differencing approach ${ }^{8}{ }^{9}$, we can use the lagged differences of all explanatory variables as instruments for the level equation and combine the difference equation (1) and the level equation (that is, the equation where $\Delta Y^{N A}{ }_{i t}$ is replaced by $Y^{N A}{ }_{i t}$ in equation (1)) in a system. Here the panel estimators use instrumental variables based on previous realisations of the explanatory variables as the internal instruments, using the Blundell-

\footnotetext{
${ }^{7}$ Here investment is based on the estimates of physical capital formation in World Development Indicators on the assumption that the physical capital formation is mainly related to non-agricultural sector investment. Estimates of investment specific to non-agricultural sector are unavailable and thus omitted in Christiaensen et al. (2011). We have tried the cases with and without investment.

${ }^{8}$ Two issues have to be resolved in estimating the dynamic panel model. One is endogeneity of the regressors and the second is the correlation between $\left(\Delta Y_{i t-1}-\Delta Y_{i t-2}\right)$ and $\left(\varepsilon_{i t-} \varepsilon_{i t-1}\right)$ (e.g. see Baltagi, 2005). Assuming that $\varepsilon_{i t}$ is not serially correlated and that the regressors in $\boldsymbol{X}_{i t}$ are weakly exogenous, the generalized method-of-moments (GMM) first difference estimator (e.g. Arellano and Bond, 1991) can be used. It should also be noted that, as Hayakawa (2007) has shown by simulations for various cases (e.g. $\mathrm{n}=50$ ), the possible biases for small sample are smaller with the SGMM estimator than with the GMM first-difference estimator. We have thus adopted the SGMM estimator to minimise the biases.

${ }^{9}$ We have presented Arellano-Bond test for zero autocorrelation in first-differenced errors and Sargan test of overidentifying restrictions for each table. In most cases, the results of the former show the first-order correlations of the first differenced errors which justify including the one-period lagged dependent variable. Considering the fact that $\boldsymbol{Z}_{i t}$, endogenous variables - which are instrumented by their own lags tend to be persistent over time and thus Sargan test rejects the null hypothesis that over-identifying restrictions are valid in some cases (i.e., Cases 1,3, 4, 5 and 6 of Table 1, Case 5 of Table 3) and the results in these cases should be interpreted with caution. Over-identifying restrictions are deemed valid in other cases (i.e., Case 2 of Table 1, all the cases of Table 2, Cases 1, 2, 3, 4, and 6 of Table 3). Using different specifications (e.g. including external instruments, treating $\boldsymbol{Z}_{i t}$ as exogenous) does not overcome this difficulty.
} 
Bond's (1998) SGMM estimator based on additional moment conditions. Such a system gives consistent results under the assumptions that there is no second order serial correlation and the instruments are uncorrelated with the error terms. The Blundell-Bond SGMM estimator is used in the present study. This estimator is useful to address the problem of endogenous regressors, $\boldsymbol{Z}_{i t}$ (e.g. lagged agricultural growth in equation (1)). In the system of equations, endogenous variables can be treated similarly to lagged dependent variables. The second lagged levels of endogenous variables could be specified as instruments for the difference equation. The first lagged differences of those variables could also be used as instruments for the level equation in the system.

In a similar way, agricultural growth is estimated by replacing $\Delta Y^{N A}{ }_{i t}$ with $\Delta Y^{A}{ }_{i t}$ in equation (1). We have dropped $\log$ of investment from $\boldsymbol{Z}_{i t} \cdot{ }^{10}$ We have included precipitation. ${ }^{11}$

$$
\Delta Y^{A}{ }_{i t}=\sum_{j=1}^{P} \alpha_{j} \Delta Y^{A}{ }_{i t-j}+\sum_{j=1}^{Q} \gamma_{j} \Delta Y^{N A}{ }_{i t-j}+\boldsymbol{X}_{i t} \cdot \beta_{1}+\boldsymbol{Z}_{i t} \cdot \beta_{2}+\eta_{i}+\varepsilon_{i t}
$$

\section{$2^{\text {nd }}$ Stage: Estimation of Inequality Change (or Poverty) by predicted non-agricultural growth and agricultural growth}

Based on the estimation results of (1) and (2), we further estimated changes in inequality by nonagricultural growth and agricultural growth which were predicted in the second stage.

\footnotetext{
${ }^{10}$ Comprehensive data on agricultural investment comparable across different countries are not available. The share of agricultural land and the number of tractors - which are admittedly inappropriate proxies for agricultural investment - are available from World Development Indicators and the use of these data will not significantly change the final results. Because they are not appropriate as a proxy for agricultural investment, we show the results without using the proxy.

${ }^{11}$ The case with precipitation is shown only for low income countries because it yielded insignificant or counter-intuitive results in other cases. Including precipitation will not change the results significantly.
} 
$\Delta I_{i t}=\gamma_{0}+\gamma_{1} \Delta I_{i t-1}+\gamma_{2} \widehat{\Delta Y}_{i t}+\gamma_{3}{\widehat{\Delta Y^{N A}}}_{i t}+\boldsymbol{Z}^{\prime}{ }_{i t} \cdot \gamma_{4}+\eta_{i}^{\prime}+\varepsilon^{\prime}{ }_{i t}$

where $\Delta I_{i t}$ is the first difference of the inequality measure (based on the expanded or raw EHII data), which is estimated by its first lag, the predicted values of agricultural and non-agricultural growth $\left(\widehat{\Delta Y}^{A}{ }_{i t}\right.$ and $\left.\widehat{\Delta Y^{N A}}\right)$ as well as a vector of endogenous variables, $\boldsymbol{Z}^{\prime}{ }_{i t}$, such as, $\log$ of schooling years and political stability which is taken from the World Bank's World Governance Indicators. This is estimated by the Blundell-Bond SGMM estimator with the finite-sample correction. The equation is estimated by the fixed effects model with the robust estimator for the Gini coefficient due to small sample size.

While the determinants of inequality or its changes have been analysed theoretically as well as empirically in the macro and development economics literature, there is no single consensus, as far as we aware, as to what sort of models should be used for inequality or its change. The earlier theoretical literature draws upon Kuznets's $(1955,1963)$ hypothesis of the inverted U relation between inequality and GDP per capita. Under the hypothesis, at the initial stage of development, inequality increases as GDP per capita increases, for instance, as (i) the rural-urban inequality gap as well as (ii) the inequality within the urban sector increases. This is caused by rural-to-urban migration as urban areas are industrialised, while urban wage workers' pay rise does not match the increase in profits of capital owners. While the agricultural sector features low per capita income and relatively little inequality within the sector (Barro, 2000), in the process of development, the inequality within rural sector may increase while the agricultural sector reduces its size, in which only a subset of households is likely to benefit from mechanisation and/or rural-to-urban migration. Under these circumstances, both agricultural and non-agricultural growth is likely to increase inequality at the early stage of development. 
However, inequality is supposed to decrease after a significant number of people benefit from industrialization. ${ }^{12}$ More recently, Acemoglu and Robinson (2002) proposed a political economy model of the Kuznets Curve where they emphasised the role of political stability and democratisation, leading to institutional changes and thus redistribution. In Barro's (2000) specification for inequality, he controlled for not only log GDP per capita, but also schooling and political and institutional indices. On the other hand, Bourguignon and Morrisson (1998) modelled the inequality being determined by the relative labour productivity of non-agricultural and agricultural sectors. Our empirical specification draws upon Bourguignon and Morrisson (1998) as well as Barro (2000), but we have adopted a simplified version as Equation (3) guided by the data availability. ${ }^{13}$

$$
P_{i t}=\gamma_{0}^{\prime}+\gamma_{1}^{\prime} \widehat{\Delta Y}_{i t}^{A}+\gamma_{2}^{\prime}{\widehat{\Delta Y Y_{i t}^{N A}}}+\boldsymbol{Z}_{i t}^{\prime} \cdot{ }^{\prime} \gamma_{3}+\eta^{\prime \prime}{ }_{i}+\varepsilon^{\prime \prime}{ }_{i t}
$$

Finally, poverty head count ratio or poverty gap based on either US $\$ 1.25$ or US $\$ 2$ poverty line (denoted as $P_{i t}$ in Equation (4)) is estimated by $\widehat{\Delta Y}^{A}{ }_{i t}$ and ${\widehat{\Delta Y Y^{N A}}}_{i t}$ using the robust fixed effects model to examine the relationship between agricultural or non-agricultural growth and poverty. Because the international poverty data are available only for a limited number of years, we are unable to take the first difference of poverty, or to estimate the dynamic panel model with lagged dependent variables.

\footnotetext{
${ }^{12}$ While the empirical literature on Kuznets hypothesis typically tests signs of a square and a cube of GDP per capita to examine the inverted U relationship between inequality and GDP per capita, we do not include these terms as this is not our primary objective. In most specifications, squared agricultural and non-agricultural terms are found to be statistically insignificant.

${ }^{13}$ Ideally, we should model the effect of sectoral growth on sectoral inequality, that is, inequality within agricultural or non-agricultural sector (or rural or urban sector) in Equation (3). However, we use an aggregate measure of inequality of the country $\left(I_{i t}\right)$ as such data are not available.
} 


\section{Econometric Results}

Tables 1 and 2 report the estimation results of equations (1) and (2) for three-year average panel for three cases - (i) a full sample, (ii) middle income countries and (iii) low income countries. ${ }^{14}$ For each case, two sets of results are shown. The first case is the parsimonious case with only the first difference of log of non-agricultural (or agricultural) value added per capita (the first lag), the log of agricultural (or non-agricultural) value added per capita and the share of mining industry (the second lag) ${ }^{15}$. Additional explanatory variables, such as log of schooling years or $\log$ of investment, are added in the second case.

\section{[Table 1 to be inserted]}

Table 1 shows that the growth in agricultural sector has a statistically significant effect on non-agricultural growth, based on the full sample (regardless of the specification, that is, in Cases 1 and 2) and in Case 4 (for only middle income countries with other explanatory variables). It is not significant for low income countries. This is consistent with the observation that, as the country grows and shifts from the low income to the middle income category, the nature of agriculture typically changes from subsistence-oriented farming to more commercialised and market farming and it has a closer linkage with non-agricultural sector. The elasticity estimates of non-agricultural growth rate with respect to agricultural growth rate range from 0.14 to 0.22 . That is, a $10 \%$ increase in the growth rate in agricultural value added per capita (e.g. from $10 \%$ growth to $11 \%$ growth) would be associated with $1.4 \%$ to $2.2 \%$ increase in

\footnotetext{
${ }^{14}$ If we use the annual panel, we find that (i) agricultural growth is significantly associated with nonagricultural growth in all the cases with elasticity ranging from 0.10 to 0.16 ; (ii) the lagged dependent variable is statistically significant only for low income countries; and (iii) inequality is not associated with non-agricultural growth. These results will be furnished on request.

${ }^{15}$ Inclusion of mining share follows Christiaensen et al. (2011).
} 
the growth rate of non-agricultural value added per capita (e.g. from $10 \%$ growth to $10.1 \%$ to 10.2\% growth). This is in contrast with Christiaensen et al. (2011) who showed that there is no effect from agricultural growth to non-agricultural growth. ${ }^{16}$

As in Christiaensen et al. (2011), there is a strong persistent effect in non-agricultural growth as reflected in the positive coefficient estimate of the lagged dependent variable and mining sector does not affect non-agricultural growth. In Case 2, investment growth, schooling years, and inequality (which are treated as endogenous, and instrumented by their own lags) are found to be positive and significant. Positive effects of physical and human capital are consistent with the empirical growth literature. In Case 2, we observe positive effects of (endogenous) inequality on growth. Why inequality (in level) leads to higher non-agricultural growth is not clear and needs further investigation. ${ }^{17} \mathrm{We}$ will use Case 2 to examine the linkages between agricultural and non-agricultural growth and inequality change in Table $3 .^{18}$

In Table 2 we estimate the effect of non-agricultural growth on agricultural growth. Table 2 reports positive and significant coefficient estimates of lagged growth in non-agricultural value added on growth of agricultural value added in Case 1 based on a full sample and Case 3 for middle income countries. ${ }^{19}$ However, it is negative and significant in Cases 6A and 6B for low income countries. A lagged dependent variable is positive with significant estimates observed

\footnotetext{
${ }^{16}$ This may be because we have used a more recent sample comprising a different set of countries. We have tried the same regressions by restricting them to the period before 2005. Consistent with Christiaensen et al. (2011), the coefficient of agricultural growth on non-agricultural growth becomes statistically insignificant in all cases.

${ }^{17}$ A possible reason is that a higher (initial) inequality in a poor country might enable wealthier people to invest in high-return and high-risk activities and increase the overall efficiency of the non-farm sector. If the country's wealth is more equally distributed with a majority under the poverty line, such efficient investment may not be easy. Overall, at the earlier stage of development, rural society is homogeneous with lower inequality, but inequality will rise as the country grows at a certain threshold (Kuznets, 1955, 1963).

${ }^{18}$ The choice of Case 2 is guided by the specification test results showing that there is no second order serial correlation and that over-identifying restrictions are valid.

${ }^{19}$ These results will be unchanged if we run the same regression using the sample before 2005 .
} 
only for low income countries. The share of mining sector is negative for the full sample, with the coefficient estimate significant only in Case 2. This result could be related to the large literature on the Dutch Disease where, for instance, Nigerian cocoa farmers uprooted cacao plants following the petroleum boom in the 1970s (Roemer, 1985). It is, however, positive and significant for low income countries (in Cases 6A and 6B) and negative and insignificant for middle income countries. The positive effect could reflect positive externalities from the mining sector to agricultural sector (e.g. better roads, power supply), while the negative effect could be due to displacement of the agricultural sector by the mining sector. Human capital enhances agricultural growth. Inequality is not associated with agricultural growth dynamically. Precipitation enhances agricultural growth in low income countries. ${ }^{20}$ It can be inferred through the comparison of Case 1 of Table 1 and Case 1 of Table 2 that agricultural growth generates spillovers (0.22) twice as large as those of non-agricultural growth (0.11).

\section{[Table 2 to be inserted]}

Using Case 2 (a full sample with control variables) of Tables 1 and 2, we have obtained predicted values of agricultural and non-agricultural growth. We have then applied Blundell and Bond's (1998) SGMM model where a dependent variable is the change in inequality. Three panels (Cases 1-2, 3-4 and 5-6) in Table 3 report the results based on the expanded EHII data on inequality covering the largest number and years of countries, the Gini coefficient, and the raw

\footnotetext{
${ }^{20}$ When we use the annual panel data, we find significant coefficient estimates of growth of nonagricultural value added per capita in all the cases, with a larger coefficient estimate for low income countries. Based on a full sample, we find that the mining share is positive and significant. Inequality (treated endogenous) is positively and significantly associated with agricultural growth dynamically. Precipitation is statistically insignificant.
} 
EHII data on inequality, respectively. Here our main focus is on the dynamic linkages between growth in agricultural and non-agricultural sectors and change in inequality over time. ${ }^{21}$

Reflecting the differences in coverage of countries as well as in definition of inequality, the results vary in these three panels. In Case 1 of Table 3, agricultural growth is negatively and significantly associated with inequality change and its (absolute) effect is generally larger than that of non-agricultural growth. That is, if a country experiences a higher level of agricultural growth, the pace of accentuation of inequality is curbed (or the pace of inequality reduction is accelerated) dynamically, ceteris paribus. We do not see these effects for non-agricultural growth. This is consistent with the view that if growth is driven by agriculture, it is more "inequality reducing" over time than non-agriculture (Case 1). However, agricultural growth ceases to be statistically significant in Case 2 with a few control variables (education and political stability) and non-agricultural growth becomes statistically significant. ${ }^{22}$

\section{[Table 3 to be inserted]}

In Cases 3 and 4 of Table 3, neither agricultural nor non-agricultural growth is significant in which the change in the Gini coefficient is a dependent variable. ${ }^{23}$ We observe a strong persistence in the change in the Gini coefficient in Cases 3 and 4. So in these cases agricultural

\footnotetext{
${ }^{21}$ Selected results based on the five year average data are reported in Appendix 3. The first and second columns show that lagged agricultural growth positively influences non-agricultural growth, but the lagged non-agricultural growth negatively affects agricultural growth.

${ }^{22}$ The difference between Case 1 and Case 2 of Table 3 (i.e. agricultural growth becomes statistically non-significant, while non-agricultural growth becomes significant in Case 2) appears to be due to the fact that schooling and governance are more highly and positively correlated with agricultural growth (with the coefficient of correlation of 0.625 and 0.404 , respectively) than with non-agricultural growth ( 0.157 and 0.046, respectively).

${ }^{23}$ Predicted agricultural growth is negative and significant in explaining the change in the Gini coefficient (Appendix 3).
} 
and non-agricultural growth terms do not affect inequality changes. In Cases 5 and 6, the raw EHII data are used for the measure of inequality and the dynamic model is applied. In these cases agricultural growth is not statistically significant, while non-agricultural growth is negative and significant in Case 6 where schooling and political stability are added as control variables. This is consistent with the inequality reducing effect of non-agricultural growth which we have found in Case 2. While the results vary depending on the specifications, agricultural growth has an inequality-reducing effect in the case without controlling for schooling years and political stability. Once we control for these variables, non-agricultural sector has some inequalityreducing effect.

When we use the 5 year average data, both agricultural and non-agricultural growth are found to reduce the change in inequality and these effects are statistically significant based on the expanded dataset of inequality (the third column of Appendix 3). The effect of agricultural growth in reducing the change in inequality is larger than that of non-agricultural growth in its absolute terms. It is noted that predicted agricultural growth is negatively and significantly associated with the change in the Gini coefficient, implying a role of agricultural sector in reducing inequality in the relatively long run (the fourth column of Appendix 3).

As an extension we have also used the (unbalanced) annual panel data to estimate the effects of predicted agricultural growth and non-agricultural growth on inequality. Both agricultural and non-agricultural growth terms reduce inequality when the expanded EHII data on inequality is used with the coefficient estimate larger for the non-agricultural growth in the absolute term. This result suggests that non-agricultural growth tends to reduce inequality faster in the short 
run. The sectoral growth terms are not statistically significant when the Gini coefficient or the raw data on inequality is used. ${ }^{24}$

Given the variation of signs of agricultural and non-agricultural growth terms, it is difficult to derive a single conclusion about the effects of sectoral growth on inequality. However, if we rely on the results of the dynamic panel model in Table 3 based on three years average data where the model adjusts for short-term fluctuations and measurement errors as well as takes account of the endogeneity of sectoral growth, we can conclude that agricultural growth has some inequality reducing effect (Case 1 of Table 3). The same pattern of the results is found when we use the five-year average panel data where the effect of agricultural growth is larger than that of nonagricultural growth. This is found for both the expanded inequality data and for the Gini coefficient. We have also found that non-agricultural growth accelerates inequality reduction once we control for schooling years and political stability.

Inequality index used in the analysis for Table 3 reasonably captures overall economic inequality of a country (Galbraith and Kum, 2005). However, given the aforementioned limitation of our inequality measure, it would be also useful to see how agricultural growth or non-agricultural growth affects poverty, which is defined by the poverty headcount ratio or the poverty gap, following Christiaensen et al. (2011). ${ }^{25}$ Table 4 reports the results on the effect of agricultural or non-agricultural growth on poverty headcount ratio or poverty gap - for a full sample of countries (Panel A), middle income countries (Panel B) and low income countries (Panel C). Following Christiaensen et al. (2011), we apply the country-fixed effects model ${ }^{26}$ and

\footnotetext{
${ }^{24}$ The results will be provided on request.

${ }^{25}$ If we generate the first differences in poverty, the number of observations will be reduced significantly due to missing observations. So we use these poverty indices in levels, rather than first differences.

${ }^{26}$ The Hausman test results favour fixed effects model over random effects model.
} 
use only predicted values of agricultural or non-agricultural growth (based on Case 2 in Table 1 and Case 2 in Table 2) without adding further control variables. ${ }^{27} 28$

Table 4 shows that agricultural growth has a stronger and significant effect in reducing both poverty headcount ratio and poverty gap regardless of whether the US $\$ 1.25$ a day poverty line or the US 2.00 a day poverty line is adopted, while there is no statistically significant effect of nonagricultural growth on either poverty headcount or poverty gap. ${ }^{29}$ The pattern of the results is broadly unchanged if we restrict the sample only to middle income countries where agricultural growth is found to reduce poverty regardless of which definition is used. On the other hand, in the case of low income countries, with the caveat that this is based on a small number of observations, we find a statistically significant coefficient estimate of agricultural growth only in Case 10 on poverty gap based on US\$1.25 line. Poverty reducing effects of agricultural growth are weaker in terms of their magnitude for low income countries than for middle income countries. Non-agricultural growth is negative and statistically insignificant for both middle and low income countries, with the coefficient estimates larger for the latter. We confirm that agricultural growth has a stronger poverty-reducing effect than non-agricultural growth. This is

${ }^{27}$ Adding further control variables is difficult in the regressions in Table 4 as we use a restricted sample with disaggregated sectoral data available in this section. Nor did Christiaensen et al. (2011) in their poverty regressions. It should also be noted that use of other cases (Case 1 of Tables 1 and 2) will not change the results significantly.

${ }^{28}$ As an extension, we have applied common correlated effects mean group (CCEMG) estimator (Pesaran, 2006) and the MG (mean group) model (Pesaran and Smith, 1995) to annual panel data to model the country-level heterogeneity in estimating the relationship between inequality change and agricultural/nonagricultural growth. This model provides us with the coefficient estimate for each country to show how the linkages between inequality change and agricultural (or non-agricultural) growth differ across countries. We have then applied OLS to estimate the underlying determinants for them by simply regressing the saved coefficient on exogenous variables. It has been found that, if a country is more ethnically fractionalised, it tends to have a higher (i.e., more positive or less negative) value in the coefficient indicating the effect of agricultural growth on inequality changes. This implies that the role of agriculture in reducing accentuation of inequality is likely to be undermined by ethnic fractionalisation which tends to make economic inequality more persistent. The results will be furnished on request.

${ }^{29}$ However, significant poverty-reducing effects of agricultural and non-agricultural growth are found only in a few cases (e.g. poverty gap based on US\$1.25) when the 5 year average data are used (Columns 6-9, Appendix 3). 
consistent with Table 4 of Christiaensen et al. (2011, p.248) which shows a stronger poverty reducing effect at the US\$1 threshold, but not Table 7 (p.249) in which while agricultural and non-agricultural growth significantly reduce US\$2 poverty, the effect of non-farm sector growth becomes more prominent as its effect is larger than that of agricultural growth in 4 out of 8 cases and statistically significant in all cases. A similar pattern, however, is found in Case 11 where non-agricultural growth is statistically significant, while agricultural growth is not.

\section{[Table 4 to be inserted]}

\section{Concluding Observations}

Drawing upon cross-country panel data for developing countries, the present study sheds new empirical light on the dynamic and long-term linkages among agricultural growth, inequality and poverty in developing countries. Using robust econometric models, we have analysed in detail whether agricultural growth impacts inequality and poverty after taking account of the dynamic linkages between the agricultural and the non-agricultural sectors over time. To understand the relative role of agricultural sector, we have compared the effect of agricultural growth and that of non-agricultural growth on inequality and poverty. The analyses draw upon both dynamic and static panel models using three-year averages covering the period 1969-2010. The main findings are summarised below from a policy perspective.

First, we generally observe strong growth linkages between agricultural and non-agricultural sectors for all developing countries (full sample) and middle income countries. Lagged agricultural growth - which is treated as an endogenous variable in the model - tends to promote non-agricultural growth, while lagged (endogenous) non-agricultural growth also tends to 
enhance agricultural growth. We, however, have found that agricultural growth generates spillovers twice as large as those of non-agricultural growth.

Second, in the case where the expanded EHII data are used, agricultural growth is found to reduce accentuation of inequality, or accelerate inequality reduction. While such inequality reducing effects of agricultural growth are found in the short-run based on the annual panel, nonagricultural growth tends to reduce inequality faster in the short run. In this case, the degree of ethnic fractionalisation is key to explaining the magnitude of negative linkages between agricultural/non-agricultural growth and inequality changes in the short term. That is, the role of agricultural sector reducing accentuation of inequality is likely to be undermined by ethnic fractionalisation which tends to make inequality more persistent. When we use the five-year average panel data, the agricultural growth tends to reduce significantly not only the inequality based on the expanded EHII data, but also the Gini coefficient.

Third, agricultural growth reduces poverty - both headcount ratios and poverty gaps - in both middle income and low income countries. Such poverty reducing effects are not clearly observed for non-agricultural growth. Our results thus reinforce the role of overall agricultural sector in promoting overall economic growth and reducing poverty.

A policy implication that could be derived from the present study is that interactions between agricultural and non-agricultural sectors matter as they would promote sectoral growth and reduce poverty and inequality in the long run. As suggested by the two-sector model by Restuccia et al. (2008), it is crucial for poor countries to remove barriers to intermediate inputs in making use of modern inputs as the sector uses modern production technologies. Furthermore, the transformation of agricultural sector, for instance, through changing cropping patterns with declining shares of grains and rising shares of non-grains, in particular, fruits, vegetables, dairy 
products, and meat, will promote the interaction between agricultural and non-agricultural sectors and help reduce poverty. Governmental policies to facilitate these processes for agricultural transformation would be important for reduction of poverty and inequality in the long run.

The World Bank recently strongly endorsed the case for promoting rural-urban migration and concomitant shift of resources towards efficient urbanisation, as reported in Global Monitoring Report 2013, Monitoring the MDGs (World Bank, 2013). However, this claim has been robustly rejected by our analysis that reinforces the case for revival of agriculture. Our conclusion - based on sophisticated econometric modelling and updated data - is consistent with the World Bank's earlier position supporting the role of agricultural sector in reducing poverty (e.g. World Development Report 2008 (World Bank, 2007)) ${ }^{30}$.

Agricultural sector continues to have strong linkages with the non-agricultural sector and has substantial potential for reducing inequality and poverty. More seriously, if our analysis has any validity, the lop-sided shift of emphasis to urbanisation rests on not just shaky empirical foundations but could mislead policy makers and donors. Those left behind in rural areas especially the poor - deserve better and more resources to augment labour productivity in agriculture to speed up overall growth and eliminate worst forms of deprivation in the post-2015 scenario.

\section{References}

Acemoglu, D., \& Robinson, J. A. (2002). The Political Economy of the Kuznets Curve. Review of Development Economics, 6(2), 183-203.

\footnotetext{
${ }^{30}$ World Bank (2007) concludes that '(I)n the 21st century, agriculture continues to be a fundamental instrument for sustainable development and poverty reduction' (p.1).
} 
Arellano, M., \& Bond, S. (1991). Some tests of specification for panel data: Monte Carlo evidence and an application to employment equations. Review of Economic Studies, 58, 277297.

Alesina, A., Devleeschauwer, A., Easterly, W., Kurlat, S., \& Wacziarg, R. (2003). Fractionalization. Journal of Economic Growth, 8, 155-194.

Arellano, M., \& Bover, O. (1995). Another look at the instrumental variable estimation of errorcomponents models. Journal of Econometrics, 68, 29-51.

Baltagi, B.H. (2005). Econometric Analysis of Panel Data. Third Edition. Chichester: John Wiley \& Sons Ltd.

Barro, R.J. (2000). Inequality and Growth in a Panel of Countries. Journal of Economic Growth, $5,5-32$.

Barro, R.J., \& Lee, J. (2010). A New Data Set of Educational Attainment in the World, 19502010. NBER Working Paper No. 15902. Cambridge MA: NBER.

Bourguignon, F., \& Morrisson, C. (1998). Inequality and development: the role of dualism. Journal of Development Economics. 57. 233-257.

Blundell, R., \& Bond, S. (1998). Initial conditions and moment restrictions in dynamic panel data models. Journal of Econometrics, 87, 115-143. A.

Christiaensen, L., Demery, L., \& Kuhl, J. (2011). The (evolving) role of agriculture in poverty reduction: An empirical perspective. Journal of Development Economics, 96(2), 239-254.

de Janvry, A., \& Sadoulet, E. (2010). Agricultural Growth and Poverty Reduction: Additional Evidence. The World Bank Research Observer, 25(1), 1 - 20.

Deininger, K., \& Squire, L. (1996). A New Data Set Measuring Income Inequality. World Bank Economic Review, 10, 565-591. 
Doyle, M. W., \& Stiglitz, J.E. (2014). Eliminating Extreme Inequality: A Sustainable Development Goal, 2015-2030, Ethics \& International Affairs, 28(1), 5-13.

Foster, J., Greer, J., \& Thorbecke, E. (1984). A class of decomposable poverty measures. Econometrica, 52(3), 761-766.

Galbraith, J. K., \& Kum, H. (2005) Estimating the Inequality of Household Incomes: A Statistical Approach to the Creation of a Dense and Consistent Global Data Set, Review of Income and Wealth, 51(1), 115-143.

Haggblade, S., \& Hazell, P. (1989). Agricultural technology and farm-nonfarm growth linkages. Agricultural Economics, 3(4), 345-364.

Haggblade, S., Hazell, P. \& Dorosh, P. (2007). Sectoral growth linkages between agriculture and the rural nonfarm economy. In Haggblade, S., Hazell, P., \& Reardon, T. (eds), Transforming the Rural Nonfarm Economy-Opportunities and Threats in the Developing World. Baltimore, Johns Hopkins University Press.

Hayakawa, K. (2007). Small sample bias properties of the system GMM estimator in dynamic panel data models. Economics Letters, 95, 32-38.

Herzer, D, \& Vollmer, S. (2012). Inequality and growth: evidence from panel cointegration. Journal of Economic Inequality, 10, 489-503.

Imai, K. S., Gaiha, R., and Garbero, A. (2016). Poverty Reduction during the Rural-Urban Transformation: Rural Development is Still More Important than Urbanisation, Discussion Paper Series DP2016-25, Research Institute for Economics \& Business Administration, Kobe University.

Johnston, B. F., and Mellor, J. W. (1961). The role of agriculture in economic development. American Economic Review, 51(4), 566-593. 
Kuznets, S. (1955). Economic growth and income inequality. American Economic Review, 45, 128.

Kuznets, S. (1963). Quantitative aspects of the economic growth of nations. Economic Development and Cultural Change, 12, 1-80.

Mellor, J. W., (1966) The Economics of Agricultural Development. Ithaca, New York, Cornell University Press.

Pesaran, M.H. (2006). Estimation and inference in large heterogeneous panels with a multifactor error structure. Econometrica, 74, 967-1012.

Pesaran, M.H., \& Smith, R. (1995). Estimating long-run relationships from dynamic heterogeneous panels. Journal of Econometrics, 68, 79-113.

Rehman, A., Jingdong, L., Khatoon, R., Iqbal, M. S., \& Hussain, I. (2016). Effect of Agricultural Growth on Poverty Reduction, its Importance and Suggestions. Transylvanian Review, 24(5).

Restuccia, D., Yang, D. T., and Zhu, X. (2008). Agriculture and aggregate productivity: A quantitative cross-country analysis. Journal of Monetary Economics, 55(2), 234-250.

Roemer, M. 1985. Dutch disease in developiong countries: swallowing bitter medicine. In Lundahl (ed), The Primary Sector in Economic Development, pp.201-226.

Timmer, C. P. (2015). The Dynamics of Agricultural Development and Food Security in Southeast Asia: Historical Continuity and Rapid Change. Handbook of Southeast Asian Economics, 89-113.

Townsend, R. M. (1994). Risk and Insurance in Village India. Econometrica, 62(3), 539-591.

United Nations (2013). Inequality Matters, Report on the World Social Situation 2013. New York, United Nations, http://www.un.org/en/development/desa/publications/world-socialsituation-2013.html. 
Windmeijer, F. (2005). A finite sample correction for the variance of linear efficient twostep GMM estimators. Journal of Econometrics.126, 25-51.

World Bank (2007). World Development Report 2008: Agriculture for Development, Washington DC, World Bank.

World Bank (2013). Global Monitoring Report 2013: Monitoring the MDGs, Washington DC, World Bank.

World Bank (2014). World Development Indicators, Washington DC, World Bank. 
Table 1: Effect of Agricultural Growth on Non-Agricultural Growth Dynamic Panel Regressions (Blundell and Bond (1998) SGMM): Dependant Variable: D.Log Non Agricultural Value Added per capita (based on 3- Year Average Panel Data)

\begin{tabular}{|c|c|c|c|c|c|c|}
\hline VARIABLES & Case 1 & Case 2 & Case 3 & Case 4 & Case 5 & Case 6 \\
\hline & \multicolumn{2}{|c|}{ Full Sample } & \multicolumn{2}{|c|}{$\begin{array}{l}\text { Middle Income } \\
\text { Countries }\end{array}$} & \multicolumn{2}{|c|}{$\begin{array}{l}\text { Low Income } \\
\text { Countries }\end{array}$} \\
\hline $\begin{array}{l}\text { D.Log Non Agricultural Value Added per } \\
\text { capita }(-1)\end{array}$ & $\begin{array}{l}0.261^{\star \star \star} \\
(0.0988)\end{array}$ & $\begin{array}{l}0.309^{\star \star *} \\
(0.0535)\end{array}$ & $\begin{array}{l}0.223^{\star \star} \\
(0.105)\end{array}$ & $\begin{array}{l}0.211^{\star \star} \\
(0.102)\end{array}$ & $\begin{array}{l}0.502^{\star \star \star} \\
(0.129)\end{array}$ & $\begin{array}{l}0.504^{\star \star \star} \\
(0.129)\end{array}$ \\
\hline $\begin{array}{l}\text { D.Log Agricultural Value Added per } \\
\text { capita [Endogenous] }\end{array}$ & $\begin{array}{l}0.224^{\star * *} \\
(0.0865)\end{array}$ & $\begin{array}{c}0.143^{\star} \\
(0.0761)\end{array}$ & $\begin{array}{c}0.122 \\
(0.0761)\end{array}$ & $\begin{array}{l}0.171^{\star *} \\
(0.0840)\end{array}$ & $\begin{array}{l}0.0702 \\
(0.141)\end{array}$ & $\begin{array}{l}0.088 \\
(0.153)\end{array}$ \\
\hline $\begin{array}{l}\text { The Share of Mining Sector Income in } \\
\text { GDP (-2) [Endogenous] }\end{array}$ & $\begin{array}{l}0.000488 \\
(0.00781)\end{array}$ & $\begin{array}{l}0.000773 \\
(0.00586)\end{array}$ & $\begin{array}{l}-0.00398 \\
(0.00926)\end{array}$ & $\begin{array}{l}-0.00254 \\
(0.00738)\end{array}$ & $\begin{array}{l}0.000118 \\
(0.00593)\end{array}$ & $\begin{array}{l}-0.00172 \\
(0.00542)\end{array}$ \\
\hline D.Log Investment [Endogenous] & $\begin{array}{l}- \\
-\end{array}$ & $\begin{array}{l}0.214^{\star \star *} \\
(0.0310)\end{array}$ & - & - & $\begin{array}{l}- \\
-\end{array}$ & - \\
\hline Log Schooling Years (-1) [Endogenous] & - & $\begin{array}{l}0.0205^{\star} \\
(0.0117)\end{array}$ & - & $\begin{array}{l}- \\
-\end{array}$ & $\begin{array}{l}- \\
-\end{array}$ & - \\
\hline Log Inequality [Endogenous] & $\begin{array}{l}- \\
-\end{array}$ & $\begin{array}{c}0.00186^{*} \\
(0.000971)\end{array}$ & - & - & - & - \\
\hline $\begin{array}{l}\text { D.Log Agricultural Value Added per } \\
\text { capita * SSA Dummy [Endogenous] }\end{array}$ & $\begin{array}{l}- \\
-\end{array}$ & $\begin{array}{l}- \\
-\end{array}$ & - & $\begin{array}{l}-0.0719 \\
(0.121)\end{array}$ & - & $\begin{array}{l}0.0201 \\
(0.146)\end{array}$ \\
\hline Constant & $\begin{array}{c}0.0443 \\
(0.0128)\end{array}$ & $\begin{array}{l}-0.0686 \\
(0.0484)\end{array}$ & $\begin{array}{c}0.0455 \\
(0.0155)\end{array}$ & $\begin{array}{c}0.0436 \\
(0.0150)\end{array}$ & $\begin{array}{c}0.0540 \\
(0.0194)\end{array}$ & $\begin{array}{c}0.0534 \\
(0.0194)\end{array}$ \\
\hline Observations & 532 & 400 & 414 & 414 & 113 & 113 \\
\hline Number of Countries & 59 & 50 & 44 & 44 & 14 & 14 \\
\hline \multicolumn{7}{|c|}{ Arellano-Bond test for zero autocorrelation in first-differenced errors (H0: No autocorrelation) } \\
\hline $\begin{array}{c}\text { Prob }>\text { z } \\
\text { Order } 1 \\
2 \\
\end{array}$ & $\begin{array}{c}0.0030^{* * *} \\
0.1916\end{array}$ & $\begin{array}{c}0.0032^{* * *} \\
0.2548\end{array}$ & $\begin{array}{c}0.0098^{* * *} \\
0.1894\end{array}$ & $\begin{array}{c}0.0094^{* * *} \\
0.1853\end{array}$ & $\begin{array}{l}0.1308 \\
0.2813\end{array}$ & $\begin{array}{l}0.1266 \\
0.2379\end{array}$ \\
\hline \multicolumn{7}{|c|}{ Sargan test of overidentifying restrictions ( $\mathrm{HO}$ : overidentifying restrictions are valid) } \\
\hline Prob > chi2 & $\begin{array}{c}\text { Chi2(316) } \\
375.66 \\
0.00118^{\star *}\end{array}$ & $\begin{array}{c}\text { Chi2(399) } \\
414.60 \\
0.2848\end{array}$ & $\begin{array}{c}\text { Chi2(307) } \\
392.864 \\
0.0007^{\star \star \star}\end{array}$ & $\begin{array}{c}\text { Chi2(366) } \\
457.17 \\
0.0008^{\star * *}\end{array}$ & $\begin{array}{c}\text { Chi2(133) } \\
170.30 \\
0.0161^{\star *}\end{array}$ & $\begin{array}{c}\text { Chi2(143) } \\
183.08 \\
0.0133^{\star *}\end{array}$ \\
\hline
\end{tabular}


Table 2: Effect of Non-Agricultural Growth on Agricultural Growth: Dynamic Panel Regressions (Blundell and Bond (1998) SGMM) Dependant Variable: D.Log Agricultural Value Added per capita (Based on 3- Year Average Panel Data)

\begin{tabular}{|c|c|c|c|c|c|c|c|}
\hline VARIABLES & Case 1 & Case 2 & Case 3 & Case 4 & Case 5 & Case 6A & Case 6B \\
\hline & \multicolumn{2}{|c|}{ Full Sample } & \multicolumn{2}{|c|}{$\begin{array}{c}\text { Middle Income } \\
\text { Countries }\end{array}$} & \multicolumn{3}{|c|}{$\begin{array}{c}\text { Low Income } \\
\text { Countries }\end{array}$} \\
\hline $\begin{array}{l}\text { D.Log Agricultural Value Added Per } \\
\text { Capita (-1) }\end{array}$ & $\begin{array}{c}0.0528 \\
(0.0633)\end{array}$ & $\begin{array}{c}0.0313 \\
(0.0729)\end{array}$ & $\begin{array}{c}0.034 \\
(0.0587)\end{array}$ & $\begin{array}{c}0.0338 \\
(0.0762)\end{array}$ & $\begin{array}{l}0.234^{\star \star} \\
(0.0954)\end{array}$ & $\begin{array}{c}0.185^{\star} \\
(0.0959)\end{array}$ & $\begin{array}{l}0.179^{\star} \\
(0.104)\end{array}$ \\
\hline $\begin{array}{c}\text { D.Log Non-Agricultural Value Added } \\
\text { Per Capita } \\
\text { (-1) [Endogenous] }\end{array}$ & $\begin{array}{l}0.111^{\star \star} \\
(0.0497)\end{array}$ & $\begin{array}{l}0.0483 \\
(0.0540)\end{array}$ & $\begin{array}{l}0.110^{\star} \\
(0.0596)\end{array}$ & $\begin{array}{l}0.0571 \\
(0.0569)\end{array}$ & $\begin{array}{l}0.0675 \\
(0.0852)\end{array}$ & $\begin{array}{l}-0.155^{\star \star \star} \\
(0.0527)\end{array}$ & $\begin{array}{l}-0.179 * * \star \\
(0.0639)\end{array}$ \\
\hline $\begin{array}{l}\text { The Share of Mining Sector Income in } \\
\text { GDP (-2) [Endogenous] }\end{array}$ & $\begin{array}{l}-0.00694 \\
(0.00523)\end{array}$ & $\begin{array}{l}-0.00735^{\star \star} \\
(0.00375)\end{array}$ & $\begin{array}{l}-0.00871 \\
(0.00602)\end{array}$ & $\begin{array}{l}-0.00659 \\
(0.00457)\end{array}$ & $\begin{array}{l}0.000451 \\
(0.00590)\end{array}$ & $\begin{array}{l}0.00752^{\star \star} \\
(0.00305)\end{array}$ & $\begin{array}{l}0.0152^{\star *} \\
(0.00635)\end{array}$ \\
\hline $\begin{array}{l}\text { Log Schooling Years (-1) } \\
\text { [Endogenous] }\end{array}$ & $\begin{array}{l}- \\
-\end{array}$ & $\begin{array}{l}0.0276^{\star *} \\
(0.0126)\end{array}$ & $\begin{array}{l}- \\
-\end{array}$ & $\begin{array}{l}0.0295^{\star \star} \\
(0.0123)\end{array}$ & - & $\begin{array}{l}0.0360^{\star \star \star} \\
(0.0129)\end{array}$ & $\begin{array}{l}0.0331^{\star *} \\
(0.0133)\end{array}$ \\
\hline Log Inequality [Endogenous] & $\begin{array}{l}- \\
-\end{array}$ & $\begin{array}{c}0.000327 \\
(0.000991)\end{array}$ & $\begin{array}{l}- \\
-\end{array}$ & $\begin{array}{c}0.00103 \\
(0.00112)\end{array}$ & $\begin{array}{l}- \\
-\end{array}$ & $\begin{array}{c}-0.0024 \\
(0.00146)\end{array}$ & $\begin{array}{l}-0.00207 \\
(0.00186)\end{array}$ \\
\hline Log Precipitation & $\begin{array}{l}- \\
-\end{array}$ & $\begin{array}{l}- \\
-\end{array}$ & $\begin{array}{l}- \\
-\end{array}$ & $\begin{array}{l}- \\
-\end{array}$ & - & $\begin{array}{l}- \\
-\end{array}$ & $\begin{array}{l}0.0356^{\star} \\
(0.0204)\end{array}$ \\
\hline Constant & $\begin{array}{c}0.0258 \\
(0.00821)\end{array}$ & $\begin{array}{l}-0.0303 \\
(0.0508)\end{array}$ & $\begin{array}{c}0.0263 \\
(0.0102)\end{array}$ & $\begin{array}{l}-0.0678 \\
(0.0579)\end{array}$ & $\begin{array}{c}0.0335 \\
(0.0109)\end{array}$ & $\begin{array}{c}0.114 \\
(0.0512)\end{array}$ & $\begin{array}{l}-0.128 \\
(0.173)\end{array}$ \\
\hline $\begin{array}{l}\text { Observations } \\
\text { Number of Countries }\end{array}$ & $\begin{array}{c}532 \\
59\end{array}$ & $\begin{array}{c}400 \\
50\end{array}$ & $\begin{array}{c}414 \\
44\end{array}$ & $\begin{array}{c}324 \\
37\end{array}$ & $\begin{array}{c}113 \\
14\end{array}$ & $\begin{array}{l}71 \\
12\end{array}$ & $\begin{array}{l}71 \\
12\end{array}$ \\
\hline \multicolumn{8}{|c|}{ Arellano-Bond test for zero autocorrelation in first-differenced errors (H0: No autocorrelation) } \\
\hline $\begin{array}{c}\text { Prob }>z \\
\text { Order } 1 \\
2 \\
\end{array}$ & $\begin{array}{c}0.0008^{* * *} \\
0.0770^{*}\end{array}$ & $\begin{array}{c}0.0030^{* * *} \\
0.4439\end{array}$ & $\begin{array}{l}0.0026^{* * *} \\
0.0820^{*}\end{array}$ & $\begin{array}{c}0.0048^{* *} \\
{ }^{*} \\
0.4279 \\
\end{array}$ & $\begin{array}{c}0.0654^{*} \\
0.9015\end{array}$ & $\begin{array}{c}0.00239^{* *} \\
0.9958\end{array}$ & $\begin{array}{c}0.0285^{\star *} \\
0.8563 \\
\end{array}$ \\
\hline \multicolumn{8}{|c|}{ Sargan test of overidentifying restrictions (H0: overidentifying restrictions are valid) } \\
\hline Prob > chi2 & $\begin{array}{c}\text { Chi2(316) } \\
301.88 \\
0.7067\end{array}$ & $\begin{array}{l}\text { Chi2(385) } \\
3969.54 \\
0.2940\end{array}$ & $\begin{array}{c}\text { Chi2(307) } \\
309.89 \\
0.4431\end{array}$ & $\begin{array}{l}\text { Chi2(32 } \\
9) \\
346.81 \\
0.2395\end{array}$ & $\begin{array}{c}\text { Chi2(133) } \\
134.87 \\
0.4385\end{array}$ & $\begin{array}{c}\text { Chi2(104) } \\
112.82 \\
0.2608\end{array}$ & $\begin{array}{c}\text { Chi2(103) } \\
107.81 \\
0.3533\end{array}$ \\
\hline
\end{tabular}


Table 3: Effect of Predicted Agricultural/Non-Agricultural Growth on Inequality Change:

Dependent Variable: D.Inequality: (based on 3- year average panel)

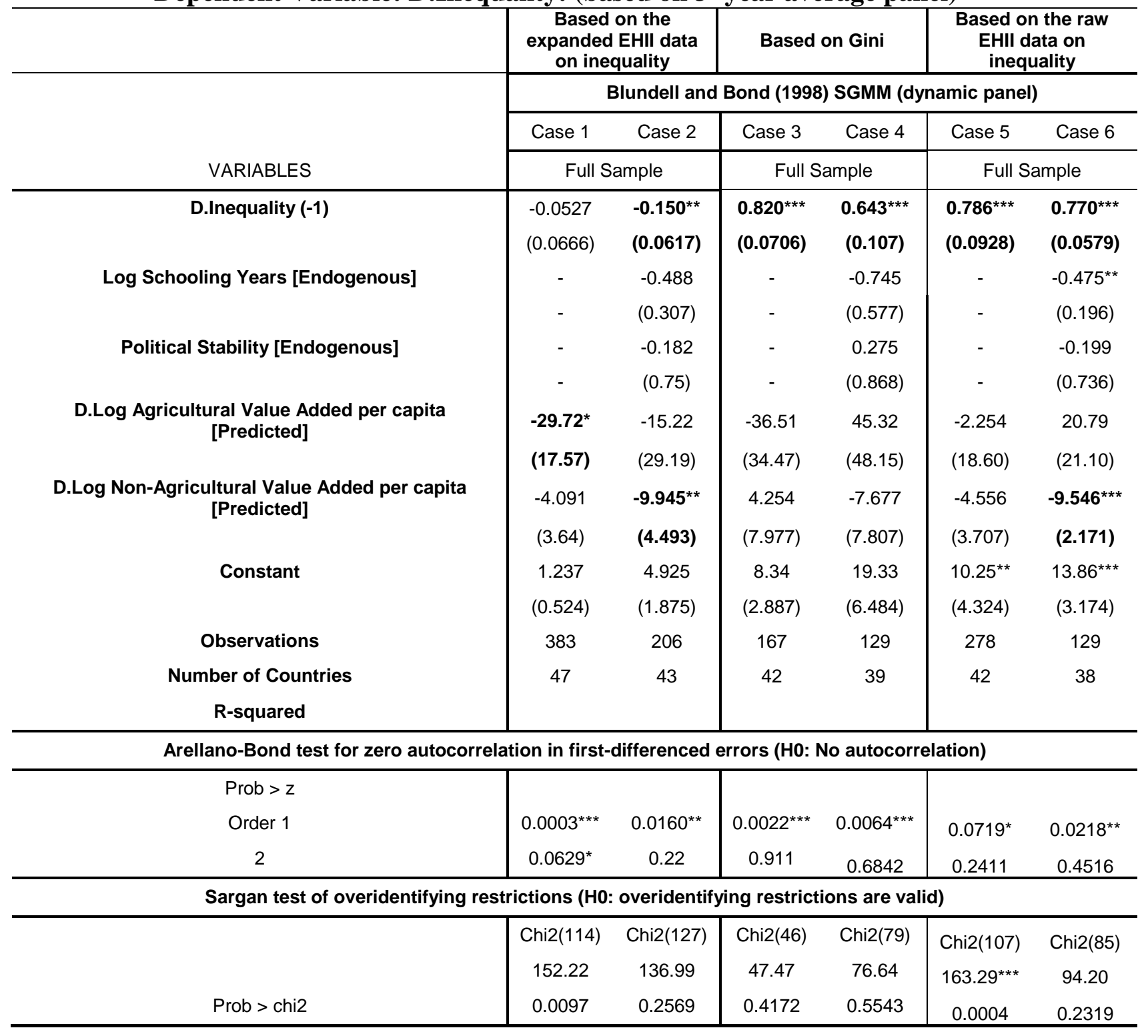


Table 4: Effect of Predicted Agricultural/Non-Agricultural Growth on Poverty: Based on 3 -year panel, country fixed effects estimation

Panel A: Full Sample

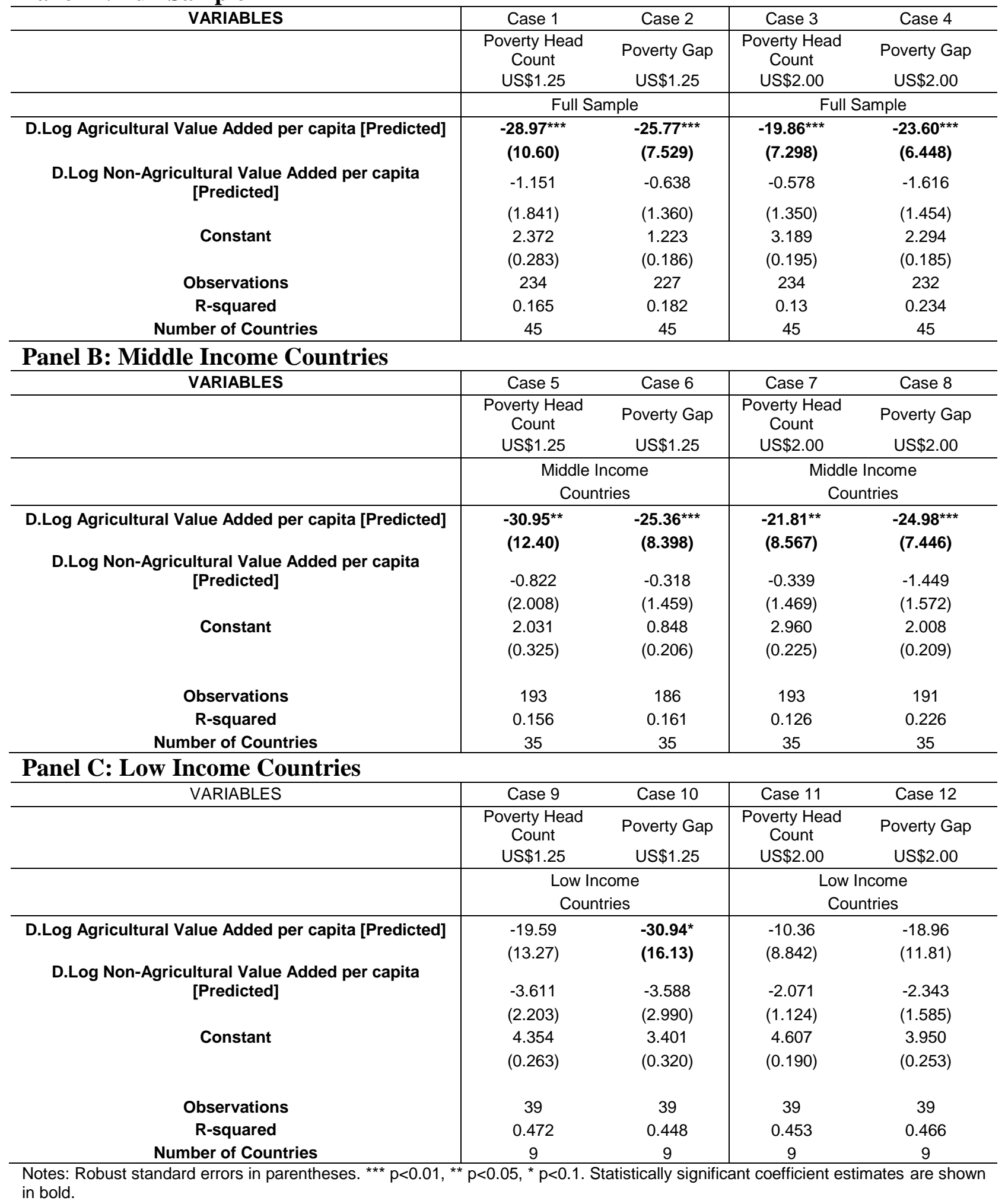




\section{Appendix 1: A List of countries included in the base case (Case 2, Table 1 and 2)}

Albania, Algeria, Argentina, Bangladesh, Bolivia, Brazil, Bulgaria, Cameroon, Chile, China, Colombia, Congo, Rep., Cote d'Ivoire, Ecuador, Egypt, Arab Rep., Gabon, Guatemala, Hungary, India, Indonesia, Iran, Islamic Rep., Jordan, Kazakhstan, Kyrgyz Republic, Lithuania, Malaysia, Mauritania, Mexico, Moldova, Morocco, Pakistan, Peru, Philippines, Poland, Romania, Russian Federation, Senegal, Serbia, Slovak Republic, Slovenia, South Africa, Sudan, Tajikistan, Thailand, Tunisia, Ukraine, Vietnam, Yemen, Rep.

\section{Appendix 2: Descriptive Statistics (3 year average)}

\begin{tabular}{|c|c|c|c|c|c|c|}
\hline Variable & & Mean & Std. Dev. & Min & $\operatorname{Max}$ & Observations \\
\hline Log agricultural value & overall & 4.522191 & 3.528402 & -14.31253 & 6.508571 & 400 \\
\hline \multirow[t]{2}{*}{ Added per capita } & between & & 2.832785 & -14.25602 & 6.205418 & $\mathrm{n}=$ \\
\hline & within & & 0.1558084 & 3.927754 & 5.064494 & $T=$ \\
\hline \multirow{3}{*}{$\begin{array}{l}\text { log non agricultural } \\
\text { value added per capita }\end{array}$} & overall & 6.396096 & 3.972115 & -14.26882 & 9.725732 & 400 \\
\hline & between & & 3.261406 & -14.00379 & 9.543673 & $\mathrm{n}=$ \\
\hline & within & & 0.3189024 & 4.79499 & 7.975028 & $T=$ \\
\hline \multirow{3}{*}{$\begin{array}{l}\text { log share of mining } \\
\text { sector }\end{array}$} & overall & 0.6489725 & 2.200495 & -7.736457 & 4.60517 & 393 \\
\hline & between & & 2.470386 & -7.341874 & 4.60517 & $\mathrm{n}=$ \\
\hline & within & & 0.7346914 & -2.297781 & 6.016172 & $\mathrm{~T}=8.02041$ \\
\hline log average schooling & overall & 1.64029 & 0.5785531 & 0.0544562 & 2.46232 & $\mathrm{~N}=$ \\
\hline \multirow[t]{2}{*}{ Years } & between & & 0.5572342 & 0.3357747 & 2.441865 & $\mathrm{n}=$ \\
\hline & within & & 0.2778844 & 0.6884905 & 2.329862 & $T=8.16$ \\
\hline \multirow[t]{3}{*}{ Inequality measure ${ }^{* 1}$} & overall & 44.93206 & 5.86294 & 26.10158 & 56.32093 & $N=$ \\
\hline & between & & 5.206041 & 33.52282 & 53.96552 & $\mathrm{n}=$ \\
\hline & within & & 2.842125 & 31.66142 & 51.97356 & $\mathrm{~T}=6.78571$ \\
\hline \multirow{3}{*}{$\begin{array}{l}\text { Log poverty head count } \\
\text { ratio (based on US } \$ 1.25 \text { ) }\end{array}$} & overall & 1.388775 & 2.209113 & -4.60517 & 4.431055 & 234 \\
\hline & between & & 2.103891 & -3.69173 & 4.069453 & $\mathrm{n}=$ \\
\hline & within & & 0.9697695 & -3.631829 & 4.875062 & $\mathrm{~T}=$ \\
\hline \multirow{3}{*}{$\begin{array}{l}\text { Log poverty head count } \\
\text { ratio (based on US } \$ 2.00 \text { ) }\end{array}$} & overall & 2.530772 & 1.773186 & -4.60517 & 4.583027 & $N=$ \\
\hline & between & & 1.799346 & -3.066161 & 4.460227 & $\mathrm{n}=$ \\
\hline & within & & 0.7233758 & -1.4441 & 5.213912 & $T=$ \\
\hline \multirow{3}{*}{$\begin{array}{l}\text { Log poverty gap } \\
\text { (based on US\$1.25) }\end{array}$} & overall & 0.3851648 & 1.924393 & -4.055864 & 3.670206 & 227 \\
\hline & between & & 1.838318 & -3.290796 & 2.874465 & $\mathrm{n}=$ \\
\hline & within & & 0.7717002 & -2.221556 & 2.801716 & $T=5.04444$ \\
\hline
\end{tabular}




\begin{tabular}{|c|c|c|c|c|c|c|}
\hline \multirow{3}{*}{$\begin{array}{l}\text { Log poverty gap } \\
\text { (based on US } \$ 1.25 \text { ) }\end{array}$} & overall & 1.445092 & 1.846722 & -4.60517 & 4.082103 & 232 \\
\hline & between & & 1.843677 & -3.613397 & 3.676857 & $\mathrm{n}=$ \\
\hline & within & & 0.7269117 & -1.945267 & 3.921741 & $T=5.15556$ \\
\hline
\end{tabular}

Note: '. Inequality measure is based on the EHII data - combining the UNIDO and the Deininger and Squire datasets - taken from the University of Texas Inequality Project (http://utip.gov.utexas.edu/data.html).

Appendix 3: Results based on the 5 years average panel data

\begin{tabular}{|c|c|c|c|c|c|c|c|c|c|}
\hline & $\begin{array}{c}\text { Non- } \\
\text { Agricultural } \\
\text { Growth }\end{array}$ & $\begin{array}{c}\text { Agricultu- } \\
\text { ral } \\
\text { Growth }\end{array}$ & $\begin{array}{l}\text { D.Inequality } \\
\text { Expanded } \\
\text { EHII data }\end{array}$ & $\begin{array}{l}\text { D.Ineq- } \\
\text { uality } \\
\text { Gini }\end{array}$ & $\begin{array}{c}\text { D.Ineq- } \\
\text { uality } \\
\text { Raw } \\
\text { EHII } \\
\text { data }\end{array}$ & $\begin{array}{l}\text { Poverty } \\
\text { Head } \\
\text { Count } \\
\text { US\$1.25 }\end{array}$ & $\begin{array}{l}\text { Poverty } \\
\text { Gap } \\
\text { US\$1.25 }\end{array}$ & $\begin{array}{l}\text { Poverty } \\
\text { Head } \\
\text { Count } \\
\text { US } \$ 2.00\end{array}$ & $\begin{array}{l}\text { Poverty } \\
\text { Gap } \\
\text { US\$2.00 }\end{array}$ \\
\hline Dep Var & $\begin{array}{c}\text { D.lognoagriva } \\
\text { pc }\end{array}$ & $\begin{array}{l}\text { D. logagriva } \\
\text { pc }\end{array}$ & $\begin{array}{c}\text { D.Inequality_F } \\
\text { ull }\end{array}$ & D.Gini & $\begin{array}{c}\text { D.Inequalit } \\
y\end{array}$ & $\begin{array}{l}\text { Logpoverty } \\
\text { hc }\end{array}$ & $\begin{array}{c}\text { logpoverty } \\
\text { g }\end{array}$ & $\begin{array}{c}\text { logpovertyh } \\
\mathrm{C}\end{array}$ & $\begin{array}{c}\text { logpoverty } \\
\text { g }\end{array}$ \\
\hline Corresponding & Table 1 & Table 2 & Table 3 & Table 3 & Table 3 & Table 4 & Table 4 & Table 4 & Table 4 \\
\hline to: & Case 2 & Case 2 & Case 1 & Case 3 & Case 5 & Case 1 & Case 2 & Case 3 & Case 4 \\
\hline \multicolumn{10}{|l|}{ L.D.lognoagriva } \\
\hline \multirow[t]{2}{*}{$\mathrm{pc}$} & $0.218^{\star \star *}$ & $-0.218^{\star \star \star}$ & - & - & - & - & - & - & - \\
\hline & $(0.0726)$ & $(0.0607)$ & - & - & - & - & - & - & - \\
\hline \multirow[t]{2}{*}{ L.dlogagrivapc } & $1.044^{\star \star \star}$ & $0.166^{\star \star \star}$ & - & - & - & - & - & - & - \\
\hline & $(0.351)$ & $(0.0582)$ & - & - & - & - & - & - & - \\
\hline \multirow[t]{2}{*}{ P.D.logagrivapc } & - & - & $-11.70^{\star \star}$ & $-13.89^{\star}$ & -3.513 & 0.696 & $-2.981^{\star}$ & 1.237 & -1.301 \\
\hline & - & - & $(4.846)$ & $(7.83)$ & (3.143) & (1.828) & $(1.640)$ & (3.008) & (1.915) \\
\hline \multicolumn{10}{|l|}{ P.D.lognoagriva } \\
\hline \multirow[t]{2}{*}{$\mathrm{pc}$} & - & - & $-7.645^{\star \star}$ & 2.872 & -0.509 & -1.02 & $-1.820^{\star \star}$ & -0.616 & $-1.613^{\star \star \star}$ \\
\hline & - & - & (3.674) & - & - & $(0.789)$ & $(0.704)$ & $(1.011)$ & $(0.573)$ \\
\hline \multirow[t]{2}{*}{ L.D.Inequality } & - & - & $0.191^{* *}$ & - & - & - & - & - & - \\
\hline & - & - & (0.0933) & - & - & - & - & - & - \\
\hline \multirow[t]{2}{*}{ Ilmining } & 0.0079 & 0 & - & - & - & - & - & - & - \\
\hline & $(0.0115)$ & $(0.006)$ & - & - & - & - & - & - & - \\
\hline \multirow[t]{2}{*}{ dloginv } & $0.285^{\star \star *}$ & & - & - & - & - & - & - & - \\
\hline & $(0.0515)$ & & - & - & - & - & - & - & - \\
\hline \multirow[t]{2}{*}{ Ilogschooling } & -0.014 & $0.0963^{* \star *}$ & - & - & - & - & - & - & - \\
\hline & $(0.0271)$ & $(0.0259)$ & - & - & - & - & - & - & - \\
\hline Constant & $\begin{array}{c}0.0695 \\
(0.0473)\end{array}$ & $\begin{array}{c}-0.05 \\
(0.0470)\end{array}$ & $\begin{array}{l}2.091 \\
(0.792)\end{array}$ & $\begin{array}{c}1.723 \\
(1.027)\end{array}$ & $\begin{array}{c}0.999 \\
(0.746)\end{array}$ & $\begin{array}{c}1.224 \\
(0.228)\end{array}$ & $\begin{array}{c}0.811 \\
(0.220)\end{array}$ & $\begin{array}{l}2.595 \\
(0.437)\end{array}$ & $\begin{array}{c}1.805 \\
(0.248)\end{array}$ \\
\hline \multirow{2}{*}{$\begin{array}{c}\text { Observations } \\
\text { Number of } \\
\text { code1 }\end{array}$} & 326 & 201 & 150 & 133 & 68 & 149 & 148 & 149 & 148 \\
\hline & 49 & 48 & 44 & 41 & 25 & 48 & 48 & 48 & 48 \\
\hline
\end{tabular}

